\title{
Analiza wpływu komponentów pirotechnicznych mieszanin opóźniających stosowanych w zapalnikach elektrycznych na ich właściwości użytkowe
}

\author{
Jolanta BIEGAŃSKA ${ }^{1)}$, Krzysztof BARAŃSKI ${ }^{2)}$
}

\begin{abstract}
${ }^{1)}$ prof. dr hab. inż.; Wydział Górnictwa i Geoinżynierii, Katedra Inżynierii Środowiska, AGH Akademia Górniczo-Hutnicza im. Stanisława Staszica w Krakowie; email: biega@agh.edu.pl

2) dr inż.; Wydział Górnictwa i Geoinżynierii, Katedra Inżynierii Górniczej i Bezpieczeństwa Pracy, AGH Akademia GórniczoHutnicza im. Stanisława Staszica w Krakowie; email: baranski@agh.edu.pl
\end{abstract}

http://doi.org/10.29227/IM-2020-01-12

Submission date: 24-11-2019 | Review date: 22-03-2020

\section{Abstrakt}

W referacie scharakteryzowano grupy składników stosowanych do produkcji mieszanek pirotechnicznych oraz określono wpływ poszczególnych komponentów na ich właściwości. Omówiono czynniki mające wplyw na efekt energetyczny mieszanin pirotechnicznych. Przedstawiono zasady stosowane przy doborze poszczególnych komponentów w celu tworzenia nowych mieszanin majacych zastosowanie w elementach opóźniających zapalników elektrycznych. Omówiono wady i zalety najcześciej stosowanych mieszanin pirotechnicznych.

Słowa kluczowe: pirotechniczna mieszanka opóźniająca, element opóźniający, zapalnik elektryczny

\section{Wprowadzenie}

Materiał wybuchowy (MW) wykazuje zdolność do wykonania pracy mechanicznej jedynie w przypadku jego prawidłowego zainicjowania. Cechą określającą progową wartość energii jaką trzeba dostarczyć by rozpocząć przemianę wybuchową jest wrażliwość. Wrażliwość materiału wybuchowego definiowana jest jako zdolność zainicjowania materiału wybuchowego pod wpływem działania bodźca zewnętrznego, którym może być: uderzenie tarcie, ciepło, przeniesienie detonacji z jednego ładunku na drugi. Większość współcześnie stosowanych materiałów wybuchowych klasycznych ze względów bezpieczeństwa charakteryzuje się niewielką wrażliwością. Dlatego by zapoczątkować przemianę wybuchową potrzebują silnego inicjatora. Inicjowanie materiałów wybuchowych odbywa się współcześnie poprzez zastosowanie lontów (detonujących, rzadziej prochowych) lub zapalników (elektrycznych, nieelektrycznych, elektronicznych). Precyzyjne odpalenie większej liczby ładunków realizowane jest z wykorzystaniem zapalników. W zapalnikach elektrycznych i nieelektrycznych w celu uzyskania odpowiednich opóźnień wykorzystuje się mechanizmy oparte na reakcji chemicznej spalania specjalnych mas palnych. Wykorzystywane $\mathrm{w}$ ten sposób masy palne w celu zachowania wysokiej precyzji działania zapalnika muszą charakteryzować się stałą prędkością spalania.

\section{Krótka historia rozwoju sposobów inicjowania ładunków}

Początkowo stosowany MW miotający (proch czarny) inicjowany był $\mathrm{w}$ bardzo prosty sposób (za pośrednictwem źdźbła słomy). Był to bardzo niebezpieczny i wysoce nieefektywny sposób odpalania materiału wybuchowego. Wynalazkiem, który ułatwił i poprawił bezpieczeństwo inic- jowanie ładunków był lont prochowy Bickforda wytworzony po raz pierwszy w $1831 \mathrm{r}$. Mimo, że stosowany jest obecnie ma kilka wad w tym głównie trudność w precyzyjnym odpaleniu większej ilości ładunków. Jego czas palenia jest zmienny i zależny od wywieranego ciśnienia zewnętrznego. Ponadto nieefektywnie odpala MW kruszące.

W 1907 r. odkryto inny środek inicjujący - lont detonujący początkowo wytwarzany $\mathrm{z}$ trotylu, a cechujący się prędkością detonacji rzędu $5000 \mathrm{~m} / \mathrm{s}$. Od lat 30-tych XX w. stosowany aż do chwili obecnej jest lont pentrytowy (Brown, 2001; Morawa, 2013; Cybulski, 1970).

Wraz $\mathrm{z}$ rozwojem nowoczesnych kruszących materiałów wybuchowych ewaluowały sposoby inicjowania ładunków. Ograniczenia lontów prochowych przyczyniły się do stworzenia konstrukcji spłonki zawierającej piorunian rtęci(II) umieszczony początkowo w papierowej a następnie w miedzianej tulejce. Pierwszy zapalnik elektryczny pojawił się w 1880 roku i był też wykonywany jako zapalnik zwłoczny. Stosowana była nazwa: „ostry” zapalnik elektryczny, tj. taki, gdzie zespół zapalczy (główka zapalnika) była połączona na trwale z częścią spłonkową. W 1900 r. opracowano zapalniki elektryczne zwłoczne co pozwoliło na zastosowanie opóźnień przy detonacji ładunków. Główki zapalcze zapalnika miały też różne konstrukcje, jak np. zapalniki szparowe, iskrowe, bocznikowe. Były one mało precyzyjne i niestabilne w działaniu. Od 1907 roku zaczęto zastępować piorunian rtęci azydkiem ołowiu (Brown, 2001). Natomiast od 1950 roku wprowadzono zapalniki mostkowe, które zapewniały większe możliwości zarówno technologiczne, jak i bezpieczeństwo ich stosowania. Zapalniki o takiej konstrukcji produkowane są także współcześnie. Etapy rozwoju zapalników przedstawia rys. 1 (Morawa, 2013 str. 133). 

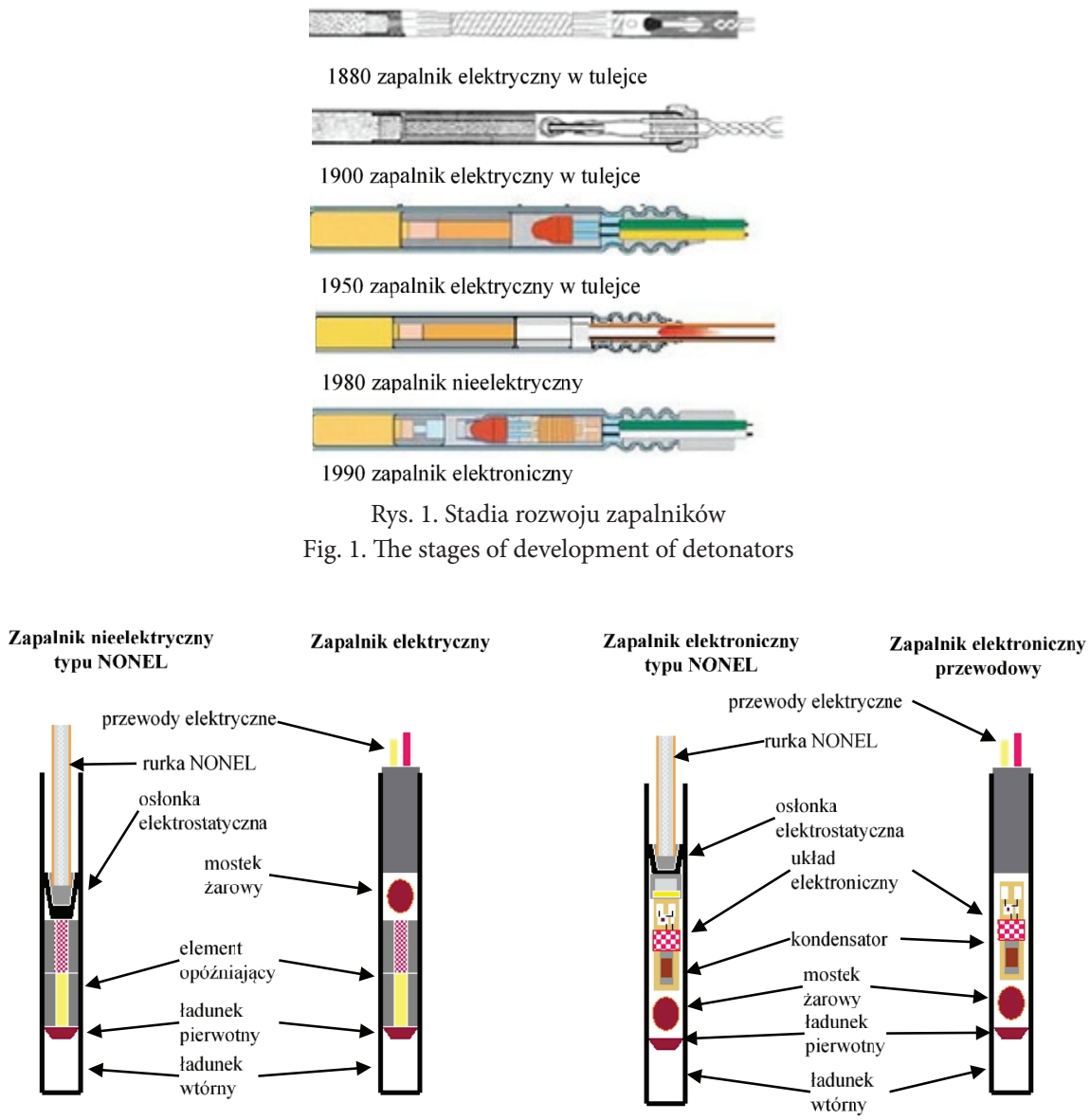

Rys. 2. Budowa obecnie stosowanych konstrukcji zapalników

Fig. 2. Construction of currently used detonators

\section{Budowa i działanie zapalnika elektrycznego}

Zapalnik elektryczny można zdefiniować jako urządzenie w którym energia elektryczna zostaje zamieniona na ciepło potrzebne do zapłonu niewielkiej ilości masy zapalczej. Uzyskany w ten sposób płomień powoduję detonację MW inicjującego (Cybulski, 1970). Zapalnik elektryczny zbudowany jest z metalowej tulei w której znajduje się jego cała konstrukcja oraz przewodów elektrycznych doprowadzających prąd elektryczny. W budowie zapalnika elektrycznego można wyróżnić następujące elementy:

- elektrostatyczna osłonka,

- główka zapalcza zawierająca mostek żarowy,

- opóźniająca masa palna (umieszczona w elemencie opóźniającym),

- materiał wybuchowy pierwotny,

- masa pośrednia (podsypka),

- materiał wybuchowy wtórny.

Prąd elektryczny przepływający przewodami zapalnika a dostarczany za pośrednictwem zapalarki elektrycznej powoduje rozgrzanie główki zapalczej. Otrzymane w ten sposób ciepło powoduje zapalenie elementu opóźniającego zapalnika. Dzięki zastosowania odpowiedniej kompozycji tego elementu następuje spalanie masy palnej ze stałą prędkością a czas zadziałania zapalnika regulowany jest długością tego elementu. W dalszym etapie dochodzi do przekazania ciepła na bardzo wrażliwy MW pierwotny - azydek ołowiu lub teneres, który detonuje. Przemieszczająca się w wyniku przemiany wybuchowej fala detonacyjna pobudza mniej wrażliwy ale silniejszy MW wtórny (pentryt lub heksogen). Postępująca fala detonacyjna propaguje poza zapalnik pobudzając ładunek zasadniczy lub pośredni (pobudzacz wybuchowy).

Porównanie konstrukcji obecnie stosowanych zapalników przedstawia rys. 2 (Opracowanie własne na podstawie Podoliak, 2004).

\section{Znaczenie milisekundowego odpalania ładunków $\mathrm{w}$ technice strzelniczej}

Badania nad wpływem opóźnień odpalania ładunków na efekt prowadzonych prac strzałowych prowadzone są od lat 40-tych XX wieku. W wyniku przeprowadzonych prac uznano, że technika milisekundowego odpalania ładunków pozwala na minimalizację negatywnych skutków oddziaływań na otoczenie oraz poprawia technologiczne efekty strzelań (Pyra, 2013). Spowodowało to upowszechnienia konstrukcji mostkowych zapalników elektrycznych zwłocznych w latach 50-tych XX w. oraz zapoczątkowało rozwój innych systemów inicjowania.

Opóźnienia międzystrzałowe stosowane podczas detonacji ładunku mają wpływ na:

- technologiczne efekty strzelań (rozdrobnienie urobku, kształt usypu),

- intensywność drgań parasejmicznych, 
Tab. 1a. Paliwa stosowane do produkcji pirotechnicznych mas opóźniających - składniki nieorganiczne (Wojewódka, 2014, str. 27-28)

Tab. 1a. Fuels used to produce pyrotechnic delay mass - inorganic components (Wojewódka, 2014, pp. 27-28)

\begin{tabular}{|l|l|}
\hline Grupa składników nieorganicznych & Skladniki \\
\hline \multirow{3}{*}{ metale i stopy metali } & $\begin{array}{l}\text { Cynk }(\mathrm{Zn}), \text { glin }(\mathrm{Al}), \text { magnez }(\mathrm{Mg}), \text { nikiel }(\mathrm{Ni}), \text { molibden }(\mathrm{Mo}), \\
\text { mangan }(\mathrm{Mn}), \text { stront }(\mathrm{Sr}), \text { żelazo }(\mathrm{Fe}), \text { chrom }(\mathrm{Cr}), \text { tytan }(\mathrm{Ti}), \text { cyrkon } \\
(\mathrm{Zr}), \text { beryl }(\mathrm{Be}), \text { wolfram }(\mathrm{W})\end{array}$ \\
\hline półmetale i niemetale & Antymon (Sb), bor (B), german $(\mathrm{Ge})$, krzem (Si), selen (Se) fosfor (P) \\
\hline \multirow{2}{*}{ związki } & proste: siarczki metali, np. $\mathrm{Sb}_{2} \mathrm{~S}_{3}, \mathrm{FeS}_{2}$ \\
\cline { 2 - 2 } & złożone: Ti-C, Cu-C. \\
\hline
\end{tabular}

- $\quad$ efekty ekonomiczne i ochronę środowiska (prawidło dobrane opóźnienia pozwalają na zmniejszenie ilości zastosowanego MW i poprawę efektywności strzelań).

Zbyt małe opóźnienia międzystrzałowe mogą spowodować (Winzer, 2016; Sołtys, 2015):

- nakładanie się czasów opóźnień kolejnych ładunków (m.in. na skutek niedokładności zadziałania zapalników) przez co efekt odpalenia serii będzie podobny jak przy zastosowaniu zapalników natychmiastowych,

- wzrost intensywności drgań,

- słabe wytworzenie się dodatkowych płaszczyzn odsłonięć,

- większe rozdrobnienie urobku.

Zbyt duże opóźnienia międzystrzałowe mogą spowodować:

- niekontrolowany efekt sejsmiczny (wzrost intensywności drgań),

- dobre wytworzenie się dodatkowych płaszczyzn odsłonięć,

- grubsze rozdrobnienie urobku, w niektórych przypadkach nadgabaryty, oraz pogorszenia stanu ociosu.

Czynniki wpływające na dobór właściwego opóźnienia można podzielić na związane z (Winzer, 2016; Wojewódka, 2014):

- budową geologiczną ośrodka skalnego (wytrzymałość skał, prędkość fali podłużnej, prędkość powstawania spękań w ośrodku skalnym, liczba i orientacja płaszczyzn odsłonięć w caliźnie, częstotliwość rezonansowa ośrodka),

- technologią prowadzenia prac strzałowych (cel robót strzałowych, geometria rozmieszczenia otworów strzałowych, rodzaj zastosowanych MW itp.).

Istnieje wiele zasad określających sposób optymalnego opóźnienia międzystrzałowego. Najczęściej spotykana określa minimalny czas zadawania kolejnych opóźnień międzystrzałowych wynoszący 8 ms (Winzer, 2016; Pyra, 2013), jednakże dobór optymalnych opóźnień międzystrzałowych powinien być zawsze poprzedzony próbnymi strzelaniami i dokładną analizą miejsca prowadzenia prac strzałowych przy rozpoznanej geologii terenu.

\section{Ogólna charakterystyka opóźniających mas pirotechnicznych}

Pirotechniczną masę opóźniającą można zdefiniować jako związek chemiczny lub mieszanina związków chemic- znych, składająca się co najmniej z paliwa i utleniacza, która prawidłowo zainicjowana lub pobudzona wykazuje zdolność w ściśle określonych warunkach do spalania z ustaloną prędkością.

Ponadto masy pirotechniczne powinny charakteryzować się odpowiednimi parametrami warunkującymi ich właściwe działanie i bezpieczeństwo użytkowania (Wojewódka, 2014; Szydłowski 1957):

- $\quad$ stałą prędkością palenia w zależności od długości elementu opóźniającego, w jak najszerszym zakresie,

- parametry spalania masy powinny być w małym stopniu zależne od temperatury otoczenia,

- nie powinny deflagrować lub detonować podczas zainicjowania, szczególnie w zamkniętej przestrzeni,

- musi być bezpieczna w użyciu i przechowywaniu,

- masa powinna wytwarzać właściwy i maksymalny efekt specjalny przy jej minimalnym zużyciu,

- powinna odznaczać się minimalną wrażliwością na działanie bodźców zewnętrznych (np. uderzenie, tarcie) oraz na zmianę temperatury,

- powinny posiadać odpowiednią stabilność chemiczną oraz fizyczną podczas długiego okresu przechowywania (wymagania techniczne podają często okres minimum 6 miesięcy bez utraty właściwości masy),

- powinny generować jak najmniejszą ilość gazów,

- powinny posiadać lekko ujemny bilans tlenowy,

- powinny być tanie i proste $\mathrm{w}$ wykonaniu, a także nie zawierać toksycznych substancji,

- $\quad$ powinny być proste $\mathrm{w}$ utylizacji, jeżeli stracą swoje właściwości.

Szczególne znaczenia ma dokładność i powtarzalność czasu spalania masy pirotechnicznej. Ze względu na charakterystykę procesu spalania pirotechniczne masy opóźniające można podzielić na (Conkling, 1985; Wojewódka 2014):

- $\quad$ masy szybkie - prędkości spalania w przedziale 30$100 \mathrm{~mm} / \mathrm{s}$,

- masy pośrednie - prędkość palenia w zakresie 10-30 $\mathrm{mm} / \mathrm{s}$,

- $\quad$ masy wolne - mają prędkość palenia w zakresie 1-10 $\mathrm{mm} / \mathrm{s}$.

\section{Grupy składników stosowane do produkcji pirotechnic-} znych mas opóźniających

Pirotechniczne masy opóźniające, podobnie jak materiały wybuchowe, składają się różnych grup składników pełniących określone funkcje w ich strukturze. Można wyróżnić następujące grupy składników: 
Tab. 1b. Paliwa stosowane do produkcji pirotechnicznych mas opóźniających - składniki organiczne (Wojewódka, 2014, str. 27-28)

Tab. 1b. Fuels used to produce pyrotechnic delay mass - organic components (Wojewódka, 2014, pp. 27-28)

\begin{tabular}{|l|l|}
\hline Grupa składników organicznych & Składniki \\
\hline węglowodany & celuloza, skrobia, laktoza, sacharoza i ich pochodne \\
\hline związki funkcyjne & aminy i kwasy karboksylowe \\
\hline metaloorganiczne związki kompleksowe & taniniany wanadu, żelaza lub ołowiu \\
\hline
\end{tabular}

Tab. 2. Utleniacze stosowane do produkcji pirotechnicznych mas opóźniających

Tab. 2. Oxidizers used for the production of pyrotechnic delay mass

\begin{tabular}{|c|c|}
\hline Grupa składników & Składniki \\
\hline \multirow[t]{7}{*}{ sole } & $\operatorname{azotany}(\mathrm{V}): \mathrm{NaNO}_{3}, \mathrm{KNO}_{3}, \mathrm{Ba}\left(\mathrm{NO}_{3}\right)_{2}, \mathrm{~Pb}\left(\mathrm{NO}_{3}\right)_{2}$, \\
\hline & chlorany(V): $\mathrm{KClO}_{3}, \mathrm{NaClO}_{3}$, \\
\hline & chlorany(VII): $\mathrm{KClO}_{4} \mathrm{i} \mathrm{NaClO}_{4}$, \\
\hline & manganiany(VII): $\mathrm{Ca}\left(\mathrm{MnCO}_{4}\right)_{2}, \mathrm{KMnO}_{4}$, \\
\hline & chromiany(VI): $\mathrm{K}_{2} \mathrm{ClO}_{4}, \mathrm{~K}_{2} \mathrm{Cr}_{2} \mathrm{O}_{7}, \mathrm{BaCrO}_{4}$ \\
\hline & $\mathrm{PbCrCO}_{4}$ \\
\hline & siarczany(VI) $\mathrm{BaSO}_{4}, \mathrm{SrSO}_{4}$, \\
\hline tlenki metali i niemetali & $\mathrm{Fe}_{2} \mathrm{O}_{3}, \mathrm{~Pb}_{3} \mathrm{O}_{4}, \mathrm{PbO}_{2}, \mathrm{CuO}, \mathrm{Cu}_{2} \mathrm{O}, \mathrm{MnO}_{2}$ \\
\hline nieorganiczne nadtlenki & $\mathrm{SrO}_{2}, \mathrm{BaO}_{2}, \mathrm{CaO}_{2}$. \\
\hline
\end{tabular}

- $\quad$ substancje palne - podtrzymujące proces palenia,

- substancje utleniające (utleniacze) - zadaniem, których jest dostarczenie tlenu do struktury mieszaniny niezbędnego do prawidłowego procesu spalania,

- modyfikatory spalania (katalizatory, flegmatyzatory) - spowalniają lub przyśpieszają reakcję spalania w zależności od potrzeby i zastosowania masy pirotechnicznej,

- lepiszcza - ułatwiające granulację mieszaniny, jej zaprasowanie oraz spajające poszczególne składniki mieszaniny,

- $\quad$ substancje pomocnicze i dodatkowe (pełniące inne funkcje, np. rozcieńczalnika).

Substancje palne powinny dostarczać dużą ilość ciepła, zapewniającą stabilną prędkość palenia, odpowiednią temperaturę produktów spalania. Związki te muszą także łatwo wchodzić w reakcje $\mathrm{z}$ utleniaczem. Ponadto (Szydłowski, 1957; Wojewódka, 2014):

- powinny cechować się łatwością reagowania z tlenem utleniacza (lub powietrza) oraz w wyniku reakcji utleniania i redukcji dawać pożądane i stabilne produkty w fazach stałej/ciekłej,

- powinny wykazywać dużą stabilność właściwości fizykochemicznych w zakresie temperatur $-60^{\circ} \mathrm{C}$ do $+60^{\circ} \mathrm{C}$,

- nie powinny być higroskopijne,

- $\quad$ przy spalaniu powinny zużywać minimalną ilość tlenu,

- powinny być łatwe i tanie w przygotowaniu,

- nie powinny być toksyczne ani rakotwórcze.

Najważniejsze paliwa organiczne i nieorganiczne stosowane do wytwarzania pirotechnicznych mas opóźniających przedstawiono w tab.1a i 1 b.

Utleniacze są podstawową grupą związków chemicznych stosowanych do produkcji pirotechnicznych mas opóźniających. Ich zadaniem jest dostarczenie możliwie dużej ilości tlenu, która gwarantuje stabilność procesu spalania.

Utleniacze stosowane do produkcji mas pirotechnicznych (Szydłowski, 1957; Concling 1985; Wojewódka, 2014):
- $\quad$ powinny zawierać możliwie największą zawartość tlenu na jednostkę objętości lub masy,

- powinny łatwo oddawać tlen podczas palenia się masy,

- powinny wykazywać dużą stabilność właściwości fizykochemicznych $\mathrm{w}$ zakresie temperatur $-60^{\circ} \mathrm{C}-$ $+60^{\circ} \mathrm{C}$,

- nie powinny być higroskopijne lub łatwo reagować $\mathrm{z}$ wodą,

- powinny być tanie i łatwe w przygotowaniu,

- nie powinny być toksyczne i rakotwórcze.

Zestawienie najczęściej stosowanych utleniaczy przedstawia tab. 2. (Wojewódka, 2014, str. 32).

Modyfikatory spalania służą do korygowania prędkości reakcji chemicznej finalnej masy palnej. W charakterze aktywatorów najczęściej stosuje się tlenki (które są tym samym drugim utleniaczem). Do hamowania reakcji stosuje się przeważnie wodorotlenki, siarczany i węglany. Wykaz najważniejszych związków chemicznych stosowanych jako modyfikatorów właściwości chemicznych przedstawiono w tab. 3 (Wojewódka, 2014 str. 38).

Lepiszcze jest składnikiem umożliwiającym zespolenie składników w celu późniejszego zaprasowania mieszaniny. Pozwala na uzyskanie wymaganej gęstości mieszaniny oraz zabezpiecza jej stabilność fizyczną. Generalnie lepiszcze powinno być łatwe w aplikacji, a jego ilość powinna być na tyle niewielka, aby nie zakłócać właściwości podstawowej mieszaniny pirotechnicznej a także wpływać negatywnie na reaktywność mieszaniny. Składniki lepiszcza nie mogą wchodzić $\mathrm{w}$ reakcje $\mathrm{z}$ pozostałymi składnikami mieszaniny pirotechnicznej oraz istotnie zmieniać jej właściwości finalnych np. wrażliwości na uderzenie. Ponadto przy wyborze tego składnika nie powinno się stosować związków chemicznych, które są toksyczne lub powodują zagrożenie dla środowiska.

\section{Ogólne zasady stosowane przy doborze poszczególnych komponentów w celu tworzenia nowych mieszanin piro- technicznych}

Duża ilość możliwych do zastosowania kombinacji paliw, utleniaczy, spoiw oraz modyfikatorów powoduje trudności 
Tab. 3. Podział modyfikatorów palenia mas ze względu na ich wpływ na prędkość reakcji chemicznej Tab. 3 Division of combustion modifiers due to their influence on the velocity of chemical reaction

\begin{tabular}{|c|c|}
\hline Rodzaj modyfikatora & Związek chemiczny \\
\hline Aktywatory & $\mathrm{MnO}_{2}, \mathrm{Mn}_{2} \mathrm{O}_{3}, \mathrm{SnO}_{2}, \mathrm{~V}_{2} \mathrm{O}_{5}, \mathrm{Bi}_{2} \mathrm{O}_{3}, \mathrm{MoO}_{3}$, \\
\hline Inhibitory & $\mathrm{B}_{2} \mathrm{O}_{3}, \mathrm{CuO}_{2}, \mathrm{CaCO}_{3}, \mathrm{Na}_{2} \mathrm{CO}_{3}, \mathrm{Ba}(\mathrm{OH})_{2}, \mathrm{ZnO}, \mathrm{Ca}(\mathrm{OH})_{2}, \mathrm{CaF}_{2}, \mathrm{NaF}, \mathrm{CaC}_{2} \mathrm{O}_{4}$, \\
\hline Neutralne & $\mathrm{SrC}_{2} \mathrm{C}_{4}$ oraz niektóre organiczne związki \\
\hline $\mathrm{TiO}_{2}, \mathrm{ZrP}_{2}, \mathrm{SiO}_{2}, \mathrm{Al}_{2} \mathrm{O}_{3}, \mathrm{Cr}_{2} \mathrm{O}_{3}, \mathrm{~K}_{2} \mathrm{O}, \mathrm{CaO}, \mathrm{BaO}, \mathrm{MgO}$ \\
\hline
\end{tabular}

w doborze poszczególnych składników masy palnej oraz ustaleniu odpowiednich proporcji.

Najważniejsze aspekty, na które należy zwrócić uwagę przy doborze składników mieszanek pirotechnicznych to:

- czystość chemiczna składników - zawartość wody oraz zanieczyszczeń,

- proporcje stechiometryczne składników,

- Średnia wielkość cząstek i charakterystyka uziarnienia,

- gęstość mieszaniny,

- prędkość palenia mieszaniny,

- parametry termodynamiczne mieszaniny,

- bilans tlenowy mieszaniny.

Do produkcji mieszanek pirotechnicznych stosuje się składniki w stanie stałym mające strukturę krystaliczną. W celu zapewnienia stabilności procesu spalania powinny cechować się najwyższą czystością. Odczynniki o niższej czystości mogą wprowadzać do mieszaniny dodatkowe substancje, zakłócające przebieg zachodzących reakcji chemicznych.

Proporcje poszczególnych składników ustala się na drodze eksperymentalnej. Reakcje egzotermicznego rozkładu powinny przebiegać z wydzieleniem możliwie największej ilości ciepła. Istnieją programy komputerowe pozwalające na teoretyczne empiryczne obliczenie parametrów takie jak EKVI Thermodynamic Sofware Package Simulation (Shepherd M. i inni, 2015). Program zawiera obszerną bazę parametrów termodynamicznych różnych substancji chemicznych pozwalających na modelowanie zachowania układu dla różnych składników przy zmiennych warunkach ciśnienia i temperatury (Yolandi C. $\mathrm{i}$ inni, 2016).

Program pozwala na obliczenie:

- energii/ciepła spalania (symulując badanie wykonane w bombie kalorymetrycznej),

- objętości wydzielanych produktów gazowych,

- temperatury palenia (symulując badanie pirometrem).

Dzięki przeprowadzonym symulacjom można uzyskać przybliżone wyniki obliczanych parametrów oraz wytypować mieszaniny, które zostaną poddane badaniom z wykorzystaniem metod instrumentalnych.

Bardzo istotnym parametrem jest rozdrobnienie i powierzchnia właściwa składników mieszaniny. Do celów pirotechnicznych wykorzystuje się substancje o wielkości cząstek wynoszącej poniżej $100 \mu \mathrm{m}$. Cząstki o większych wymiarach nie dają stabilnego procesu spalania. Większe rozdrobnienie prowadzi do zwiększenia powierzchni właściwej mieszaniny a tym samym poprawia kontakt utleniacza $\mathrm{z}$ paliwem. Poprzez zmniejszanie wielkości cząstek utleniacza i paliwa można regulować prędkość palenia mieszaniny. Inne czynniki wpływające na prędkość palenia to (Szydłowski, 1957; Wojewódka, 2014):
- właściwości reagentów - szczególnie utleniacza,

- gęstość masy - z jej wzrostem maleje porowatość mieszaniny, a tym samym proces zapalenia przebiega wolniej (zapalenie najłatwiej przebiega w masach „luzem” - niezaprasowanych),

- obecność w układzie składników łatwo ulegających topnieniu,

- temperatura początkowa zapłonu oraz od wartości ciśnienia zewnętrznego.

Gęstość masy pirotechnicznej jest efektem ciśnienia jej zaprasowania na etapie elaboracji do metalowych tulei elementu opóźniającego zapalnika. Zagęszczanie mieszaniny jest koniecznym etapem produkcyjnym stosowanym w celu elaboracji do tulei elementu opóźniającego oraz zapewnienia stabilności procesu palenia. Prasowanie mas odbywa się przy ciśnieniu 50-1000 MPa. Zbyt silne zagęszczenie może spowodować zanik zdolności palenia się masy (podobnie jak w przypadku MW tzw. „zaprasowanie na martwo”).

Bilans tlenowy jest parametrem decydującym o cieple reakcji chemicznej oraz o strukturze produktów gazowych, które tworzą się w wyniku spalania. W przeciwieństwie do zasady obowiązującej przy tworzeniu materiałów wybuchowych, masy pirotechniczne powinny cechować się ujemnym bilansem tlenowym. Masy trudno łączące się paliwem powinny posiadać lekko ujemny bilans tlenowym. Układy pirotechniczne zawierające paliwa łatwo łączące się utleniaczem mogą wykazywać niższą wartość bilansu tlenowego (Georg Steinhauser i inni, 2008; Wojewódka, 2014).

\section{Charakterystyka stosowanych kompozycji pirotechnic- znych mieszanin opóźniających}

Zestawienie najczęściej opisywanych w literaturze mas pirotechnicznych wraz z omówieniem ich wad i zalet przedstawiono w tab. 4. (Opracowanie własne)

\section{Podsumowanie}

Istnieje wiele możliwości tworzenie mieszanin, które mogą być stosowane do produkcji elementów opóźniających zapalników elektrycznych. Obecnie bardzo dużą uwagę przywiązuje się do zagadnień ochrony środowiska naturalnego co powinno przełożyć się na eliminowanie substancji toksycznych i szkodliwych z produkowanych mieszanin. Mieszaniny pirotechniczne nie powinny zawierać ołowiu, chromu oraz nadchloranów. Dyskusyjne pozostaje zastosowanie związków miedzi $\left(\mathrm{Cu}_{2} \mathrm{O}\right)$ jako utleniacza w konstrukcjach elementów opóźniających zapalników elektrycznych ze względu na możliwość tworzenia azydków miedzi w kontakcie z MW pierwotnym zapalnika - azydkiem ołowiu. Biorąc po uwagę kryterium kosztów należy unikać stosowania mieszanin opartych na drogich składnikach takich jak: wolfram, tytan, nikiel, cyrkon. 
Tab. 4. Charakterystyka najczęściej stosowanych mas pirotechnicznych

Tab. 4. Characteristics of the most frequently used pyrotechnic masses

\begin{tabular}{|c|c|c|}
\hline Masa pirotechniczna & Źródło opisujące mieszaninę & Uwagi \\
\hline $\mathrm{Si} / \mathrm{Pb}_{3} \mathrm{O}_{4}$ & Patent US2749226 & $\begin{array}{ll}\text { Wysoka toksyczność } & \text { ołowiu } \\
\text { znajdującego się w utleniaczu }\end{array}$ \\
\hline $\mathrm{Si} / \mathrm{Zr} / \mathrm{Bi}_{2} \mathrm{O}_{3}$ & Patent US5654520 & Wysoka cena cyrkonu \\
\hline $\mathrm{Ti} / \mathrm{Zr} / \mathrm{KClO}_{4}$ & Patent US2457860A & $\begin{array}{l}\text { Wysoka cena cyrkonu, toksyczność } \\
\text { nadchloranu }\end{array}$ \\
\hline $\mathrm{Mn} / \mathrm{Bi}_{2} \mathrm{O}_{3}$ & $\begin{array}{l}\text { Art.: Manganese as Fuel in Slow- } \\
\text { Burning Pyrotechnic Time Delay } \\
\text { Compositions }\end{array}$ & Mieszanina perspektywiczna \\
\hline $\mathrm{Si} / \mathrm{Bi}_{2} \mathrm{O}_{3} / \mathrm{Sb}_{2} \mathrm{O}_{3}$, & $\begin{array}{l}\text { Art.: Environmentally Benign } \\
\text { Pyrotechnic Delays } \\
\\
\text { Art.: } \mathrm{Sb}_{6} \mathrm{O}_{13} \text { and } \mathrm{Bi}_{2} \mathrm{O}_{3} \text { as Oxidants } \\
\text { for } \mathrm{Si} \text { in Pyrotechnic Time Delay } \\
\text { Compositions }\end{array}$ & Mieszanina perspektywiczna \\
\hline $\mathrm{B} / \mathrm{TiO}_{2} / \mathrm{SnO}_{2}$ & Patent US $4915756 \mathrm{~A}$ & Mieszanina perspektywiczna \\
\hline $\mathrm{Zn} / \mathrm{SrO}_{2}$ & $\begin{array}{l}\text { Art.: Combustion of some zinc- } \\
\text { fuelled binary pyrotechnic systems }\end{array}$ & Mieszanina perspektywiczna \\
\hline $\mathrm{Ti} / \mathrm{SnO}_{2}$ & Patent US4374686 & Mieszanina perspektywiczna \\
\hline $\mathrm{W} / \mathrm{BaCrO}_{4} / \mathrm{KClO}_{4}$ & $\begin{array}{l}\text { Patent US4963204 } \\
\text { Patent US3726730 }\end{array}$ & $\begin{array}{l}\text { Toksyczność chromu, mieszanina } \\
\text { zawiera nadchlorany, wysoka cena } \\
\text { wolframu, niektóre związki baru mogą } \\
\text { być toksyczne. }\end{array}$ \\
\hline $\mathrm{Sb} / \mathrm{KClO}_{4} / \mathrm{Pb}_{3} \mathrm{O}_{4}$ & Patent DE 2416920 A1 & $\begin{array}{l}\text { Wysoka toksyczność } \\
\text { znajdującego się w utleniaczu. }\end{array}$ \\
\hline $\mathrm{Si} / \mathrm{PbCrO}_{4}$ & $\begin{array}{l}\text { Art.: Alternative oxidants for silicon } \\
\text { fuel in time-delay composition }\end{array}$ & Wysoka toksyczność ołowiu i chromu. \\
\hline $\mathrm{Mn} / \mathrm{Cu}_{2} \mathrm{O}$ & $\begin{array}{l}\text { Art.: Manganese as Fuel in Slow- } \\
\text { Burning Pyrotechnic Time Delay } \\
\text { Compositions }\end{array}$ & $\begin{array}{l}\text { Miedź może reagować } \mathrm{z} \text { azydkiem } \\
\text { ołowiu (MW pierwotny) dając azydki } \\
\text { miedzi. }\end{array}$ \\
\hline $\mathrm{Si} / \mathrm{BaSO}_{4} / \mathrm{Pb}_{3} \mathrm{O}_{4}$ & Patent US4419154 & $\begin{array}{l}\text { Wysoka toksyczność ołowiu, niektóre } \\
\text { związki baru mogą wykazywać } \\
\text { toksyczność. }\end{array}$ \\
\hline $\mathrm{Sb} / \mathrm{KMnO}_{4}$ & Patent US2105674 & Mieszanina perspektywiczna \\
\hline $\mathrm{Mn} / \mathrm{V}_{2} \mathrm{O}_{5}$ & $\begin{array}{l}\text { Art.: Manganese as Fuel in Slow- } \\
\text { Burning Pyrotechnic Time Delay } \\
\text { Compositions }\end{array}$ & Mieszanina perspektywiczna \\
\hline $\begin{array}{l}\mathrm{Si} / \mathrm{NaCl}, \\
\text { Układ zawieraj.: } \mathrm{Na}_{2} \mathrm{SO}_{4}, \\
\mathrm{~K}_{2} \mathrm{SO}_{4}, \quad \mathrm{Sb}_{2} \mathrm{O}_{3}, \quad \mathrm{Sb}_{2} \mathrm{O}_{5}, \\
\mathrm{PbO}, \mathrm{V}_{2} \mathrm{O}_{5}\end{array}$ & Patent US5147476 & $\begin{array}{l}\text { Wysoka toksyczność ołowiu } \\
\text { (dot. układu zawierającego PbO) }\end{array}$ \\
\hline $\mathrm{Si} / \mathrm{SnO}_{2}$ & Patent US4374686 & Mieszanina perspektywiczna \\
\hline $\mathrm{Mn} / \mathrm{MnO}_{2} /$ rozpuszczalnik & Patent WO2010068957 (A2) & Mieszanina perspektywiczna \\
\hline $\mathrm{Zn} / \mathrm{KMnO}_{4}+\mathrm{Si}+\mathrm{Ti}-\mathrm{Ni}$ & Patent US3111438 (A) & Wysoka cena tytanu i niklu. \\
\hline $\begin{array}{l}\mathrm{W} / \mathrm{BaCrO}_{4} / \mathrm{KClO}_{4} \mathrm{z} \text { dod. } \\
\left(\mathrm{BaSiF}_{6}\right) \mathrm{Si}\end{array}$ & Patent US4963204 & $\begin{array}{l}\text { Niektóre związki baru mogą być } \\
\text { toksyczne, wysoka cena wolframu, } \\
\text { wysoka toksyczność chromu, } \\
\text { mieszanina zawiera nadchlorany. }\end{array}$ \\
\hline $\begin{array}{l}\mathrm{W} / \mathrm{BaCrO}_{4} / \mathrm{KClO}_{4} \text { ziemia } \\
\text { okrzemkowa, stearynian } \\
\text { cynku }\end{array}$ & Patent US3726730 & $\begin{array}{l}\text { Mieszanina zawiera nadchlorany, } \\
\text { wysoka cena cyrkonu i niklu. }\end{array}$ \\
\hline $\begin{array}{l}\mathrm{Si} / \mathrm{Al} / \mathrm{Fe}_{3} \mathrm{O}_{4} \\
\text { (masa termitowa) }\end{array}$ & Patent US7883593 & $\begin{array}{l}\text { Mała wrażliwość, wymagane duże } \\
\text { rozdrobnienie wynoszące około } 3 \mu \mathrm{m} \text {. } \\
\text { Wysoka temperatura zapłonu } \mathrm{Fe}_{3} \mathrm{O}_{4}- \\
1000^{\circ} \mathrm{C} \text {. Wymagana masa podpałkowa } \\
\text { lub katalizator. }\end{array}$ \\
\hline $\mathrm{KClO}_{4} / \mathrm{Mg}-\mathrm{Al}$ & $\begin{array}{l}\text { Art.: Effect of different additives on } \\
\text { the thermal properties and combustion } \\
\text { characteristics of pyrotechnic } \\
\text { mixtures containing the } \mathrm{KClO} 4 / \mathrm{Mg}- \\
\mathrm{Al} \text { alloy }\end{array}$ & Mieszanina zawiera nadchlorany. \\
\hline Stopy $\mathrm{Zr} / \mathrm{B}$ oraz $\mathrm{Ti} / \mathrm{B}$ & $\begin{array}{l}\text { Art.: Investigation of the burning } \\
\text { properties of } \mathrm{Zr} / \mathrm{B} \text { type and } \mathrm{Ti} / \mathrm{B} \text { type } \\
\text { alloy delay compositions }\end{array}$ & Wysoka cena tytanu i cyrkonu. \\
\hline $\mathrm{Mn}+\mathrm{Sb}_{2} \mathrm{O}_{3}$ & $\begin{array}{l}\text { Art::Mn }+\mathrm{Sb}_{2} \mathrm{O}_{3} \text { Thermite/Intermetallic } \\
\text { Delay Compositions }\end{array}$ & Mieszanina perspektywiczna \\
\hline $\mathrm{Si}-\mathrm{CaSO}_{4}$ & $\begin{array}{l}\text { Art.: Calcium Sulfate as a Possible } \\
\text { Oxidant in "Green" Siliconbased } \\
\text { Pyrotechnic Time Delay } \\
\text { Compositions }\end{array}$ & $\begin{array}{l}\text { Mieszanina perspektywiczna } \\
\text { Opisana jako przyjazna dla środowiska }\end{array}$ \\
\hline $\mathrm{Si}-\mathrm{Sb}_{6} \mathrm{O}_{13} / \mathrm{Bi}_{2} \mathrm{O}_{3}$ & $\begin{array}{l}\text { Art.: } \mathrm{Sb}_{6} \mathrm{O}_{13} \text { and } \mathrm{Bi}_{2} \mathrm{O}_{3} \text { as Oxidants } \\
\text { for } \mathrm{Si} \text { in Pyrotechnic Time Delay } \\
\text { Compositions }\end{array}$ & Mieszanina perspektywiczna \\
\hline B- $\mathrm{K}_{2} \mathrm{FeO}_{4}$ & $\begin{array}{l}\text { Art.: Thermochemical Calculations } \\
\text { for Potassium Ferrate(VI), } \mathrm{K}_{2} \mathrm{FeO}_{4} \text {, as } \\
\text { a Green Oxidizer in Pyrotechnic } \\
\text { Formulations }\end{array}$ & Mieszanina perspektywiczna \\
\hline Stopy $\mathrm{Ti} / \mathrm{C}-3 \mathrm{Ni} / \mathrm{Al}$ & $\begin{array}{l}\text { Art.: } \mathrm{Ti} / \mathrm{C}-3 \mathrm{Ni} / \mathrm{Al} \text { as a Replacement } \\
\text { Time Delay Composition }\end{array}$ & Wysoka cena tytanu i niklu \\
\hline $\begin{array}{l}\text { MTV } \\
\mathrm{Mg}-60 \% \\
\left(\mathrm{C}_{2} \mathrm{~F}_{4}\right) \mathrm{n}-20 \% \\
\left(\mathrm{C}_{10} \mathrm{H}_{7} \mathrm{~F}_{13}\right)_{\mathrm{n}}-10 \%\end{array}$ & $\begin{array}{l}\text { Art.: Review on thermochemical } \\
\text { codes "Green" Pyrotechnics: } \\
\text { A Chemistst Challenge }\end{array}$ & Mieszanina perspektywiczna \\
\hline
\end{tabular}


Przyszłościowe wydaje się wykorzystanie mieszanin pirotechnicznych wykorzystujących jako paliwo mangan $\mathrm{w}$ kombinacji $\mathrm{z}$ różnymi utleniaczami opartymi na związkach bizmutu $\left(\mathrm{Bi}_{2} \mathrm{O}_{3}\right)$, antymonu $\left(\mathrm{Sb}_{2} \mathrm{O}_{3}\right)$ a także od niedawna badana mieszanina $\mathrm{Si}_{-} \mathrm{CaSO}_{4}$. Duże możliwości dają miesza- niny wykorzystujące związki żelaza takie jak $\mathrm{Fe}_{3} \mathrm{O}_{4}$, oraz ferraty potasu $\mathrm{K}_{2} \mathrm{FeO}_{4}$ jednakże wymagają one modyfikacji składu mieszaniny w celu wprowadzenia dodatkowej podpałki lub składników korygujących właściwości palne.

\section{Literatura - References}

Patenty

1. Patent US 2749226 A: Delay composition for delay electric detonators. 1956-06-05.

2. Patent US5654520: Delay charge and element, and detonator containing such a charge. Boberg T., Carlsson S., Ekman Britt-Barie, Karlsson Bo, 1997-08-05.

3. Patent US2457860: Delay fuse compositions. Bennett Owen, Jack Dubin, 1949-01-04.

4. Patent US 4915756: A Pyrotechnical delay charge. Calsson Staffan, Boberg Tore, Sjoeqvist Conny, 1990-04-10.

5. Patent US4374686: Delay composition for detonators. Davitt Alan 1., Yuill Kenneth A.. 1983-02-22.

6. Patent US4963204: Pyrotechnic delay compositions. Faber Guenther, Florin Hans, Grommes Peter-Josef, Roeh Peter. 1990-10-16.

7. Patent US3726730: Pyrotechnic delay composition containing heavy metal soap. Rose J., Zimmer Galler. 1973-04-10.

8. Patent DE 2416920 A1: Delay element for electric time-fuse used in mining - contg. combustible substance, metal oxide and salt of an oxygen-contg. acid. Zalachowski Wiktor, Przybylik Geb Praszmo Roza, Kandzia Horst, Śliwinski Czeslaw, Stryjek Kazimierz. 1974-10-17.

9. Patent US4419154: Delay composition for detonators. Davitt Alan 1, Yuill Kenneth. 1983-12-06.

10. Patent US2105674: Delay action detonator and fuse and delay composition for use therein. Edwin Sosson Charles. 1938-01-18.

11. Patent US5147476: Delay composition and device. Beck Michael W., Flanagan John. 1992-09-15.

12. Patent WO2010068957 (A2): Slow burning pyrotechnic delay composition. Focke Walter Wilhelm, Del Fabbro Olinto Guiseppe, Swanepoel Darren. 2010-06-17.

13. Patent US3111438: Delay compositions for delay electric detonators. Ball Thomas, Trevorrow William. 1963-11-19.

14. Patent US4963204: Pyrotechnic delay compositions. Faber Guenther, Florin Hans, Grommes Peter-Josef, Roeh Peter. 1990-10-16.

15. Patent US7883593: Non-toxic pyrotechnic delay compositions. Rose James, Michay Magdy, Puszynski Jan. 2011-0208 .

Artykuły naukowe:

16. Caroline K. Wilharm, Anton Chin, and Sara K. Pliskin. Thermochemical Calculations for Potassium Ferrate(VI), K2FeO4, as a Green Oxidizer in Pyrotechnic Formulations. Propellants, Explosives, Pyrotechnics Vol. 39(2), 173$179,2014$.

17. Swanepoel D., Del Fabbro O., Focke Walter W.: Manganese as Fuel in Slow-Burning Pyrotechnic Time Delay Compositions. Propellants, Explosives, Pyrotechnics Vol. 35(2), 105-113, 2010.

18. Ouyang D., Pan G., Guan H., Zhu Ch., Chen X.: Effect of different additives on the thermal properties and combustion characteristics of pyrotechnic mixtures containing the $\mathrm{KClO} 4 / \mathrm{Mg}-\mathrm{Al}$ alloy Thermochimica Acta 513(1-2), 119-123, 2011.

19. Miklaszewski Eric J., Poret Jay C., Shaw Anthony P., Son Steven F. and Grove: Ti/C-3Ni/Al as a Replacement Time Delay Composition. Propellants, Explosives, Pyrotechnics Vol. 39(1), 138-147, 2014.

20. Steinhauser G. and Klapotke Thomas M.: "Green” Pyrotechnics: A Chemists' Challenge. Angew. Chem. Int. Ed. Vol. 47(18), 3330-3347, 2008. 
21. Lua Kai-Tai, h Wanga Yao-Chi, Yeha Tsao-Fa, Wub Chia-Wei.: Investigation of the burning properties of Zr/B type and Ti/B type alloy delay compositions. Combustion and Flame 156(8), 1677-1682, 2009.

22. Kalombo L., Del Fabbro O., Conradie C., Focke Walter W.: Sb6O13 and Bi2O3 as Oxidants for Si in Pyrotechnic Time Delay Compositions. Propellants, Explosives, Pyrotechnics Vol. 32(6), 454-460, 2007.

23. Tribelhorn Michael J., Venables Dean S., Brown Michael E.: Combustion of some zinc-fuelled binary pyrotechnic systems. Thermochimica Acta Vol. 256(2), 309-324, 1 June 1995.

24. Ricco M. M., Focke W. W. \& Conradie C.: Alternative oxidants for silicon fuel in time-delay compositions. Combustion Science and Technology Vol. 176(9), 1565-1575, 2004.

25. Montgomery Yolandi C., Focke Walter W., Atanasova Maria, Del Fabbro Olinto and Kelly Cheryl: Mn+Sb2O3 Thermite/Intermetallic Delay Compositions Propellants, Explosives, Pyrotechnics Vol. 41(5), 919-925, 2016.

26. Sołtys, A., Winzer J., Pyra J.: Badania efektu sejsmicznego a nowoczesne systemy odpalania ładunków materiałów wybuchowych. Przegląd Górniczy T. 71, nr 9, 69-76, 2015.

27. Tichapondwa Shepherd M., Focke Walter W., Del Fabbro Olinto, and Kelly Cheryl: Calcium Sulfate as a Possible Oxidant in "Green" Siliconbased Pyrotechnic Time Delay Compositions. Propellants, Explosives and Pyrotechnics Vol. 40(4), 518-525, 2015.

Materiały konferencyjne:

28. Ernst-Christian Koch, Rutger Webb, Volker Weiser. Review on thermochemical codes. Conference: 36th International Pyrotechnics Seminar, At Rotterdam, August 2009.

29. Jay C. Poret, Anthony P. Shaw, Lori J. Groven, Gary Chen, Karl D. Oyler. Environmentally Benign Pyrotechnic. Delays 38th International Pyrotechnics Seminar, Denver, Colorado 10-15 June 2012.

30. Kathryn Podoliak. The Evolution of the Detonator. New Leaders' Conference, 21 April 2004.

31. Pyra J. Przegląd badań nad wpływem opóźnienia milisekundowego na intensywność i czas drgań wzbudzanych robotami strzałowymi w polskich kopalniach odkrywkowych. Technika Strzelnicza w Górnictwie i Budownictwie. Ustroń 2013.

Pozycje książkowe:

32. Conkling J.: Chemistry of Pyrotechnics. Marcel Dekker Inc. New York 1985.

33. Cybulski W., Krzysztolik P.: Strzelanie elektryczne w górnictwie. Wydawnictwo „Śląsk” Katowice 1970.

34. Brown G. I.: Historia materiałów wybuchowych. Wydawnictwo Książka i Wiedza 2001.

35. Morawa R.: Górnicze materiały wybuchowe i sprzęt strzałowy. Wydawnictwa Art-Tekst, Kraków 2013.

36. Winzer. J., Sołtys A., Pyra A.: Oddziaływanie na otoczenie robót z użyciem materiałów wybuchowych. Wydawnictwa AGH, Kraków 2016.

37. Wojewódka A.: Decysekundowe masy opóźniające. Monografia Politechnika Śląska, Gliwice, 2014.

38. Szydłowski A.: Podstawy pirotechniki. Wydawnictwo Obrony Narodowej, Warszawa 1957.

\section{Analysis of the Influence of Pyrotechnic Components of Delay Composition Used in Electric Detonators on their Utility}

The paper describes the groups of ingredients used in the production of pyrotechnic composition. The impact of the components on its properties was determined. The factors influencing the energy effect of pyrotechnic composition are discussed. The principles used for the selection of individual components are described in order to create new composition that are used in electric detonators' delay elements. The advantages and disadvantages of the most commonly used pyrotechnic composition are discussed.

Keywords: pyrotechnic delay composition, delay composition, electric detonator 